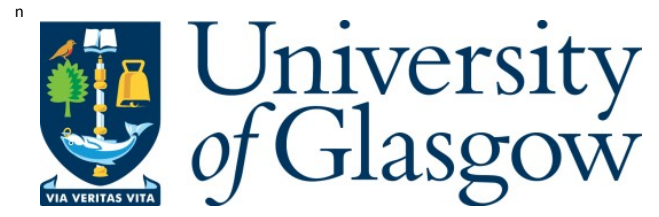

Solic, M . (2015) Representation of an absent space: construction of the U nited States and New Y ork in 1950s and 1960s Czech travel writing. Journeys: The International J ournal of Travel and Travel W riting, 16(2), pp. 60-78.

There may be differences between this version and the published version. Y ou are advised to consult the publisher's version if you wish to cite from it.

http://eprints.gla.ac.uk/110763/

Deposited on: 29 September 2015

Enlighten - R esearch publications by members of the U niversity of Glasgow http://eprints.gla.ac.uk 


\title{
Representation of an Absent Space: Construction of the United States and New York in 1950s and 1960s Czech Travel Writing
}

\author{
Mirna Šolić \\ 124 Kylepark Drive \\ Uddingston, Glasgow \\ G71 7DE \\ United Kingdom
}

Phone: +44-141-330-5592

E-mail: mirna.solic@glasgow.ac.uk

Mirna Šolić is a lecturer of Czech in the School of Modern Languages and Cultures at the University of Glasgow and currently a postdoctoral researcher in the Department of Czech Language and Literature at Palacký University, Olomouc, Czech Republic. Among her research interests are Czech literature, comparative literature, text/image studies, and travel writing, especially Czech interwar twentieth-century travel writing. She is currently working on a monograph about the travelogues of the Czech writer Karel Čapek, which she plans to publish with University of Toronto Press.

Acknowledgements:

This article as a whole is a part of the project CZ 1.07/2.3.00/30.0004. Research undertaken for this article at the University of Toronto was generously supported by a research grant awarded by The Carnegie Trust for the Universities of Scotland. I would like to thank Dr David Lightfoot for reading and providing insightful comments on the article.

Word count: 7345 words (including my biography) 


\section{ABSTRACT}

Early postwar Czech travel writing was mainly concerned with representations of countries from the newly emerging Soviet Bloc and former European colonies in the developing world. In this way, travel writing played a role in nation-building and the creation of new cultural identity. However, following the slow process of political liberalization, the United States became an increasingly visible feature of travel narratives, concomitant with interest and reception of American literature in the second part of the 1950s and throughout the 1960s. While focusing on the analysis of space and articulation of the identities of travelers/narrators, the article tracks the reemergence of the image of America in various types of travel narratives in order to depict a trajectory from the representation of a strictly bipolar world in political reportage from the early 1950s, to its subversion in the travel writing of the 1960s.

\section{KEYWORDS}

Postwar Czech travel writing; United States; Adolf Hoffmeister; Miroslav Galuška; Ludvik Aškenazy; Irena Dubská; Miroslav Holub

When in the summer of 1950 Czechoslovak travelers Miroslav Zikmund and Jiří Hanzelka ${ }^{1}$ were denied entry into the United States, they experienced on a personal level the growing tensions and looming political cold war following the 1948 communist coup in Czechoslovakia: "I [Miroslav Zikmund] also cruised along the Mississippi River, but I was not allowed to disembark on American soil. That was very humiliating. (...) I was as happy as Larry to see the United States — but we remained in a harbor and I was even not allowed to touch America" (Hanzelka and Zikmund 1998: 57-58). The coup installed pseudo-Stalinist control; in 1948 the Third Republic was dissolved, Czechoslovakia joined Comecon in 1949, and the Warsaw 
Pact in 1955. On the other side of the equation, U.S. officials were reluctant to issue clearance visas to the two travelers from a self-identified Socialist state who, on their travels through South and Central America, had filmed child labor in U.S.-operated mines that they called the "kingdom' of United Fruit Company" (58). The inaccessibility of the United States is reflected in the dearth of its representation in Czech postwar travel writing: While the nation's world tours stretched through the new Socialist world and that of its ideological allies, America remained generally absent as a topic of travel writing, only to experience a slow re-emergence in the travel literature of the 1950s and 1960s during a period of political thaw.

An examination of the gradual rediscovery of America in different travel narratives of the given period ${ }^{2}$ demonstrates the twenty-year transformation of the U.S.'s image and its culture, ${ }^{3}$ from an ideological representation in Adolf Hoffmeister's and Miroslav Galuška's ${ }^{4}$ Three Months in New York (Tři měsíce v New Yorku, 1951), to the beginnings of its artistic rediscovery and re-affirmation in Ludvik Aškenazy's ${ }^{5}$ Indian Summer (Indiánské léto, 1956), to acceptance-albeit problematic_in Irena Dubská's ${ }^{6}$ American Year (Americký rok, 1966) and Miroslav Holub's ${ }^{7}$ highly fictionalized Angel on Wheels (Anděl na kolečkách,1963). ${ }^{8}$ Galuška's and Hoffmeister's narrative is an example of the re-emergence of political reportage as one of the most preferred genres of the period, in which the new Socialist world represents "a world of joy, mutual help, and happiness" (Bauer, 2003: 3), ${ }^{9}$ in contrast to that of its negatively represented "enemies," such as the U.S. This is apparent in the use of a particular collective "we" narrative, as well as in the establishment of America as a space of binary opposition between the good and the bad. In Aškenazy's and Dubská's travel narratives, there are movements toward a lyrical description of the space allowing greater subjective involvement and emphasis of the traveling " $\mathrm{I}$ " in 
opposition to the collective narrative agent. ${ }^{10}$ Finally, "semi-reportage," the subtitle of Miroslav Holub's American travelogue, refers to the construction of a highly fragmented narrative and a play with the conventions of the political reportage of the period; however, Holub's poetic interpretation of space is based on his reading of contemporary American poets and writers, in whose works travel also plays a significant role.

In travel narratives, space is "at the least (...) 'half-created"” (Pfister 1996: 3) by the travelers/narrators, and the relationship between them is always dynamic (Barthes, 1971; 1986: 87-98). Fictionalizing tendencies in the construction of space in travel writing are informed by Hana Wirth-Nesher's interpretation of urban space in the modern novel as the interaction of four different environments: urban, natural, human, and verbal. While Wirth-Nesher does not consider the natural environment "outside the bounds of culture" (2001: 54), the natural environment in the travelogues includes "non-cultured" nature because of its impact on the representation of space. The built environment-“city layout, architecture and other man-made objects" (54) - is analyzed in relationship with the natural environment, as travelers' attitudes toward the interactions between these environments demonstrates the changes in representations of America.

The "human environment," which Wirth-Nesher defines as "human features which constitute the city setting, such as commuter crowds," as well as the "types [of people] who are generic fixtures of cities in specific periods or locales: the doorman, the street musician, the beggar, etc.," (55) is mainly represented in the travel narratives by encounters with immigrants of European descent and also beyond. They contribute to the description of the identity of the travelers, from their belonging to a certain social system (Hoffmeister, Galuška) or a certain cultural space, such as 
Europe (Aškenazy, Dubská), and finally to the lack of identification with and involvement with the creation of the transcultural experience (Holub). Finally, the verbal environment comprises different linguistic signs, such as "the names of streets and places, and (...) other language which is visually inscribed into the cityscapeadvertisements, announcements, graffiti" (56). While this latter aspect is the least represented in the travelogues, it still plays a significant role in the acceptance of American culture.

\section{The Loss of Idyllic Nature: Three Months in New York (1951)}

In Hoffmeister's and Galuška's Three Months in New York, the travelers feel the hostility of the surrounding environment immediately, at their first point of contact with another culture, the airport. They begin to understand "that we landed in enemy country, where we will not do without troubles" (1951: 74). They foresee hostility not only in the suspicious looks of the immigration officers at airport (54), but they also believe it is foreshadowed in factors beyond human control, such as the rough climate, the only reference to the world of nature in the narrative. Their experiences reflect the political context, which could be briefly defined as the atmosphere of mutual diplomatic isolationism and prejudices. On one hand, America was perceived along the aforementioned conventions of representation of a bipolar world. The travelers' experiences were shaped by “America's phobic reaction to Communism [which] permeated every arena of American life, from religious worship to Hollywood movies" (Davenport, 2009, 12), [and] which loses its grip in mid-1950s, following increased travel and cultural exchanges across the so-called Iron Curtain.

Both travelers also embody the early ideal of the "Socialist traveler" of the 1950s, who act as a collective first-person-plural narrator, often representing travel as a collective mission where "cooperation among all the members is essential for a 
successful voyage" (Robbins 1978: 216). The use of plural narration ${ }^{11}$ demonstrates "the collective consciousness of a tightly joined group who can be expected to share closely aligned ideas and emotions" (Richardson 2009: 146), and posses a "shared, collectively negotiated sense of identity within a bounded whole" (Margolin 2000: $607)^{12}$ as a significant, persuasive and highly controlled authentication of the travel experience.

In New York, the travelers experience the opposite of what the exemplary Socialist traveler would appreciate as idyllic, classic, natural beauty. Such a traveler is found in the opening article of the first issue of the geographical/travel journal Lidé a země (1952), which continued the tradition of its interwar predecessor Širým světem, negotiating its existence with publication of a number of highly ideological contributions (Borovička, 2010: 624). The traveler walking along the Vltava river not only identifies the construction of dams as a historical, Soviet-type project typical of the postwar industrial development of the country, but also acts as a nature-loving individual, inspired by the idea of industrial progress in harmony with the environment:

"A Socialist man perceives the Vltava differently. From the river he will not gain private profit. (...) That man manages to follow its flow through [the] silence of the forest, and he is careful not to disturb deer, does, foxes, and other small animals. (...) But that same man manages to roll up his sleeves (...) and build a magnificent dam at Lipno, some $40 \mathrm{~km}$ down the river" (Kahoun 1952: 6).

In contrast with their aggressive predecessors, for whom domination over nature equaled victory over history (6), socialist travelers protect nature from economic and industrial exploitation, as it represents their home and their identity. 
Such an idyllic notion is impossible to find in New York as the city is reduced to an opposition between the space of power and its subversion. The space of power is embodied in the newly constructed United Nations building, compared in the narrative to an animal habitat or "den" (74); it is also apparent among other skyscrapers and high-rises which, in contrast to European or Soviet ones, "killed the feeling for beauty" (74). ${ }^{13}$ The UN building functions as an isolated, self-sufficient, de-humanized unit with its own microclimate; the lack of natural lightning and the lack of windows impede contact with the outside world (19). However, the building as a whole physically and metaphorically operates on "slippery ground" (13): the metaphor refers to the building's intrinsic instability - the new seat of the United Nations was built on an ice-skating area donated by the mayor of New York (10).

The notion of subversion of power, on the other hand, is manifest in the Bowery, economically and socially the most deprived neighborhood of New York, which is represented as an isolated and "censored" space, separate from the officially established routes: "Here they do not take foreigners, who came for an official visit. Here is the Bowery" (123). Its inhabitants are wanderers, outcasts from society. Scenes from their everyday life are mirrored in the film advertisements which surround them: "That very moment there was a gunfight between them, with 'blood flowing'-just like on the posters in front of the nearest cinema" (124). As a part of the urban environment, advertisements remain present in other travelogues as well, from being taken in a literary sense to becoming signs of the new nature-reconciling with America as it is-in Holub's travelogue.

While the representation of the urban space of New York is mostly negative, the writers' perception of New Yorkers is more varied. Some of them are negatively described as 'bored little billionaires' wives, shareholders, priests from different 
churches" (74-75). There are the "ordinary people" (76) who failed to display political awareness according to the travelers' expectations: "Never once in our two-month stay in New York did we hear a conversation between two people about the Korean Conflict in a restaurant, in the subway or in any other public space" (75). However, there are also anonymous individuals who confidentially share their feelings with the travelers without being aware of their Socialist identities: "One evening, when Truman's speech was broadcast on the radio, a shopkeeper on the street where we stayed who did not know that we were from Czechoslovakia mysteriously approached and told us: 'You know, it would make more people happier if Truman remained a men's outfitter!"” (92). The lack of awareness of these anonymous individuals of the travelers' identities justified the travelers' Socialist ideologies, which was of greater importance to these individuals than their senses of national belonging.

\section{Establishing Contact with the Space: Ludvik Aškenazy's Indian Summer (1956)}

The name of the travelogue refers to the "sentimental" atmosphere in New York City following the destruction caused by a powerful hurricane: "Alarmed New York relaxed, red, quiet, somewhat sentimental Indian summer sneaked into Central Park" (1956: 87). The hurricane is not a hostile natural element but a part of the relationship between the natural and the urban. While the narrators in the previous narrative felt hostility right at the point of entry, here the narrator's first experience of America represents a discrepancy between pre-formed images of the country and their perception of the city's vividness: "New York stepped out of a postcard—a living city in sunny afternoon mists. All of a sudden on the sea there are a lot of small boats, helicopters, and a squadron of jet bombers on a pink horizon" (23). Additionally, the urban environment stretched into an invisible, open, and unknown realm, beyond 
human reach and mapping possibilities: "Coldly glittering New York was mysterious, and suddenly I had a feeling that it was the city, which so far I had never seen, undiscovered, unknown, huge, which I should start to get to know tomorrow. Comforting was the fact that twelve million New Yorkers would also never get to know it...“(191).

In Indian Summer, the sharp opposition between home and the foreign place is significantly less dramatic than in the previous narrative. There are frequent shifts between the collective first-person plural and first-person-singular narration, which is used to depict the narrator's intimate and personal experience of the city. "We" narration no longer refers to a group of travelers as envoys of a larger ideological collective back home, but to two travelers with individual views of America. Collective belonging is expressed by the use of the third-person narrator, a neutral collective agent who complies with travel conventions: "We returned to our hotel in the evening; our luggage was already in the room. Nobody unpacked it, because a newly arriving foreigner begins how all other foreigners begin. He went to a window, he opened it, breathed the raw, wet air of early evening, he looked and he looked. The peculiar New York sky was red, the lights of Broadway" (25). References to standardized newcomers' rituals neutralize the ideological qualifications of the space. What they see from their hotel room is everyday life. In contrast to the previous narrative, windows play a prominent role: they enable the travelers to connect with the surrounding world.

In Indian Summer, vertical dominants are not perceived as hostile; from above, New York is simply seen "from the position of a foreign bird" (63). However, the traveler prefers places where ordinary life happens. They are depicted in a photographic manner, as a set of mutually isolated shots, which, in time, resemble 
scattered "pebble stones" (189) lyrically fragmenting the narrative: "only the hot pavement of Manhattan, a tall chair in a drugstore, ${ }^{14}$ windows in a hotel room, good Mr. Kuferberg the newspaper dealer, the neon lights of Broadway and a cinema on Eighty-Fifth Avenue...and a bit was imagined by me" (189). The traveler's confession of his own "unreliability" and imagination defines his experience of the quotidian as both fact and fiction. In the spirit of modern travel writing, it follows occasions and chances and transforms New York into a series of impressions - a modern metropolis typified by alienation and loneliness.

New York also becomes a space of identification with Europe. The traveler challenges prejudices about his own Socialist country by explaining to the local people that he is not a refugee but a guest (57). At the same time, he identifies with the immigrant population, who consider Europe their lost home, thus approaching the traveler as one of their own: "She came [a hotel room cleaner] without ringing the bell, just like one person approaches another; perhaps because Duisburg is closer to Prague than to New York" (30). In the narrative of nostalgia, physical distances translate into distances between cultures, with New York becoming the place where social demarcations are internally subverted by the identity of its inhabitants.

In a similar manner, the traveler reflects on his American friend Bryan, whom he addresses in an intimate letter. It becomes evident that the travelogue is a selfconfession about the alienation that transcends the limits of actual America and becomes synonymous with the traveler's general feeling toward life: "I did not write a book about America — only about how I, as a lonely foreigner, felt sad in the rough city of New York. Maybe I was sad because I am generally sad, not only upon the East River, but also on the embankments of the Vltava" (188). Through the act of self-confession, the traveler turns attention from the actual space to himself as the 
agent of representation of the space. In this way he produces a lyrical travelogue about the city where he begins to know himself intimately and to become aware of his identity, both of which transcend physical and cultural differences.

\section{Expanding Identities: Irena Dubská's A Year in America (1966)}

In Irena Dubská's travel narrative, travel is represented as an activity of selfreflection. It is from the position of a particular space where the traveler finds herself, and not her attitude about the whole of the country, that explains her perspective on the continent:

At the beginning, New England was what is today the United States, at least by definition (certain Spanish settlements in the Southwest emerged earlier). Coincidentally, for me New England represented a region through which I approached American life and other parts of the country. Maybe my experiences there colored prejudices about what I should or should not look for, what I should or should not find in other places; a significantly different culture becomes accessible only if somewhere we manage to become a part of its everydayness (1966: 307).

However, participation in the everyday life of a foreign culture seems to be an impossible aim because it represents a combination of rituals based on "persistence, repetition, and automatism" (307) and also the absence of any pre-given model "rationally mediated" by driving through New England (307). The traveler's confession about her inability to fully participate in everyday life suggests that her detached perspective is yet another narrative step toward subverting the (ideological) claims of authoritative knowledge of a foreign place. 
The travelogue introduces an urban walker who, unlike Michel de Certeau's New York walker, does not feel that by looking at the space from above she "leaves behind the mass that carries off and mixes up in itself any identity of authors or spectators" (1985: 92). The traveler feels that the view from above helps her define her European identity as well as orient herself within the artificial structure of the city which "a long time ago slipped out from the perspective of a man on the sidewalk and on the rails" (10). The view from above also conflates the urban and the natural space, and underneath lies the complexity of the city's forgotten identity: "Only the whole view from super-human height assembles in one stroke from a fragmented and disintegrated space a neatly arranged, interconnected form, fitting into the seemingly dead floor plan, the sea, rivers, and clouds, allowing a new kind of orientation network to present itself" (10). The expansive urban environment subordinates the world of nature to the extent that its foundational support gets lost in it. In this way, the urban space resembles a labyrinth in which travelers are forced to follow welltrodden routes: "The environment, built here by man, no longer has natural support points, and when people do not exercise their usual daily pilgrimage they have trouble finding their direction in the network of underground passages and between blocks [of buildings], where immense walls obscure the sky" (10). In this manner, the traveler introduces another very important category in the representation of America: the concept of natural, or "original," identity, where the natural is pushed completely beyond the human realm.

In the narrative, authentic nature is nature beyond human reach. It is the selfsufficient space of the American desert which "exists basically beyond man; it does not threaten him, but it also does not need him and it does not offer him much" (92). Deserts belittle the importance of human presence and offer original, archetypical 
experiences of a different America: the one without needs and values imposed by humans: "persistence of scorpions and cacti is not dependent on irrigation systems" (92). For the traveler, the desert subverts the idea of Americanization. This is where, she says paraphrasing Herbert von Borsch, ${ }^{15}$ humans feel "unrest, unease and anxiety (...) As such, 'Americanization' and 'desert' are for him [the human] contrasting realities, whereby the desert is a prototype of an absolutely unpragmatic principle, like a simple waste of space and time, like a perfect self-oriented purpose" (92). Hence for the traveler, while the built environment is constantly changing, the natural simply exists.

Whereas in Aškenazy's narrative the narrator feels his European identity in contact with Americans of European origin, in Dubská's case, the sense of belonging to Europe is tied with the space of the European city. While European cities are embodiments of harmony and order between the built and the natural, American cities are troubled and conflicting entities: "The experience of chaos, disharmony, ruthlessness, formlessness, the absence of existence of whatever particular order is astonishing upon first-time European arrival" (11). While in European cities the urban prevails over the individual, in America, cities exist under direct impact of human activity, especially the endless human dissatisfaction with space. The difference between the openness and closeness of a space is a crucial difference between them. In contrast with European cities, American cities stretch into the surrounding world:

They are open spaces. Straight, broad roads always look out at an open space, on mountains, fields and sea; formless, unfinished, and temporary, they are always hounded by immense areas that surround them; they are basically only stops on the road. They are not concerned with people, they do not lock them in, they do not pressure them: from the first moment you feel that your stay 
with them is temporary-you will either leave them or they will change by themselves. It takes a moment for a European to start liking that common feature of American cities: their open, provisional character" (62).

With their fixed identities, European cities function as museums confining space and time. American cities re-evaluate history and challenge the representation of the space of the city as a permanent and unchangeable identity — as the space of home.

Similar to Aškenazy, Dubská's traveler also becomes aware of her identity in contact with New Yorkers of European descent. However, in her narrative, displacement and the search for home become intrinsic values of American civilization rather than trans-continental links to Europe. American space is populated with different types of wanderers for whom wandering means looking for an audience readily available to listen to their life stories, without demonstrating the need for deeper understanding. As one of them narrates: "And because I always travel alone, I cannot stand that nobody is waiting for me either on one end or another. And so I dream about them [my family], when I go, I think of them and I talk to them, and then I arrive and I start to drink" (125). ${ }^{16}$ While listening to their stories, the narrator becomes aware that the space in between the two coasts is populated by people who, in the absence of real homes, have invented fictional ones: Therefore, the space of America becomes characterized by spiritual homelessness.

Distances in America are both physical and metaphorical. Driving on a highway represents a search for the solitude missing from everyday life, an opportunity for commuters to be alone (322). The coasts of America (especially the West Coast) are at the same time the borders of the physical space and its fictional extensions: "And even if somebody succeeded [in reaching another coast], still it would not be the end of the story: Closeness with other human beings and a 
confidential relationship with them would prove illusory, and unfulfilled longing would be directed toward distances across the ocean" (149). San Francisco is one such place, where a long-forgotten humanity is resurrected: "The individuality of San Francisco exposes and extends in its people (...) something very basic, what was covered or distorted by the most different sediments and defense mechanisms: a need to be at home in the world, to be like a man among people" (150). In this way, the edge of the continent represents the end of the physical journey but does not discontinue the spiritual one in search of identity. New York and San Francisco, two cities situated on opposite sides, may be compared for their relative concealment and exposure. While in New York the natural environment, both physical and metaphorical, disappears under the layers of the artificially built, San Francisco is a city that unveils the missing human component, which, in the American context, is equal to finding home.

Constructing New Authenticity: Miroslav Holub's Angel on Wheels (1963)

In Miroslav Holub's "semi-reportage," the first contact with America is established from the de-familiarizing perspective of the airplane approaching the continent. Instead of the traveler, the airplane is the one who sees, and its gaze swiftly merges with the description of space based on explicit intertextual references: "But the airplane's obscene eye / sees the surface of a round world (...) Sunday parks and speechless statues, and its America / with its ghosts towns and empty Ellis Islands / and its surrealist landscape of / mindless prairies / supermarket suburbs / as Ferlinghetti says" (1963: 6). What the airplane sees is Lawrence Ferlinghetti's vision of America, transcribed verbatim from his poem "A Coney Island of the Mind" (1958); the exception that Ferlinghetti's "the poet's eye is obscenely seeing" (1958: 
13 ) is replaced with the image of the airplane's eye. In this way the third-person narrator functions as a detached and invisible witness who assigns the task of seeing to two narrative agents: a personified object and a poet for whom America (regardless of how problematic it might be) still represents the home he also traveled across. Intertextual references to Ferlinghetti and other poets in Holub's travelogue do not only function as a type of a self-censorship, an ideologically balancing act he had to satisfy using "American writers to criticize America“" (Quinn 2014: 189), ${ }^{17}$ but also to establish that the traveler wants to emphasize his international and artistic belonging rather than his national one. Such an attitude represents a significant shift when contextualized among the previous narratives: by "de-activating" his Czechness, the traveler strives for a new authenticity which subverts one of the main postulates of the travel-writing genre: the importance of cultural identification with the narrator/traveler.

Intertextual references, including Ferlinghetti's poem "A Coney Island of the Mind," give readers at least a partial picture of Holub's reading list. Holub had at his disposal 1956 translation of Walt Whitman's poetry and prose, 1959 translations of Ferlinghetti's collection A Coney Island of the Mind, which appeared in the journal Světová literatura, issue 5, and excerpts from contemporary American literature, accompanied by Igor Hájek's critical review in issue 6 in the same year. Moreover, Jan Zábrana's ${ }^{18}$ anthologies $(1959 ; 1967)$ introduced to Czech readers the latest trends in American poetry. These translations are not only important as a continuation of influence of American culture from interwar era, ${ }^{19}$ but they also reflect the postwar Czech reception and acceptance of contemporary American poetry, which becomes crucial for understanding of Czech culture. Igor Hájek argues that contemporary American poetry represented a powerful political statement against American 
establishment, and the Beats in particular represented a group which more than any other "felt so close to European and so far away from the American culture" (1959: 228).

A network of intertextual references unfolds as the traveler moves through the space. For instance, the traveler expands upon Gertrude Stein's space of America as emptied of humans from her Geographical History of America (1936) (1966: 38). The traveler likewise refers on many occasions with Henry Miller, the only one "to offer the only complete interpretation of today's American life," writing from the margins and partially literary in exile (83). Along with the Beats' subversive images of American space and the criticism of America's contemporary culture, there are also secondary references to Walt Whitman, a poet Czech readers were long familiar with, whose presence is personified through evocation of Ginsberg's encounter with him in a poem "A Supermarket in California" (1955) (39). Holub disregards the ideological reception of 1955 translation of Whitman's Grass, which celebrates the poet's appreciation of the working class as "the most important power of American society" (Čapek 1956: 8), and looks at America as a simultaneous, mosaic-like construction of different spaces and simultaneous existence of different cultural memories rather than a unifying, homogenous concept.

The personification of the plane is the beginning of a series of transformations between the inanimate and the animate in the narrative as one of the crucial tools in the traveler's vision of space. The airplane's gaze is met by the network of "eyes" from below, representing distant cities: "Ground with thousands of nervous blinking eyes, with feverish eyes, with eyes of lighthouses..." (Holub 1963: 5). As he immersed himself in American space, the traveler continued to define its 
physiognomy whereby the cities as eyes started existing as a part of a wider space resembling the human brain, and from that as an archive of collective memories:

and in thickening darkness, in darkness, like the one inside the brain, the fluorescent cities spill like memories, like hopes, like fixed ideas, like thoughts just like that, white and blue and green fluorescent cities showing a remarkable regularity towards history having names like Boston and Nantucket and New London and New Haven and Norwalk-a skull bone of the continent rumbles... (6)

The corporeal metaphor is furthermore expanded as the continent's ahistorical spirit is equated to skin without wrinkles as signs of history and memory: "[the airplane] sees the land without wrinkles, which are the wisdom of the earth" (10), ${ }^{20}$ and Minnesota as the lung tissue (9). The image of the continent as a body is broadened with an image of highway networks suggesting hands stretching into the distance: "America is not interwoven with highways: It's not true. America is pulled on highways: Like corals on strings; like sleeves on hands which reach everywhere" (12). The metaphor of stretched hands suggests a vision of America as a purely spatial context where the space defines the identity, and not the reverse.

As the central, personified feature of the space, highways start dominating over the human element and imposing an imitation of the natural as a replacement for both the natural and the human-controlled world. Human dwellings, including cities, exist either along highways or because of them. As a sign of history and ideology, a billboard placed along the highway no longer represents "an artifact, but natural vegetation" (15). In such a world, the remnants of the ancient, or the "real," authentic America depicted as a lost idyllic landscape exist beyond the main network of 
highways. That America is limited and fenced, and as such, it is almost impossible to reach:

And in both Carolinas there are big forests with herons and cottages of black people on clearings. And in California there are also wooden farms and geometrically designed plantations and boys fly kites in the spring. And horses graze. And there are thickets and an eagle on an old tree. But all of that is fenced and from highways you will not get there; the highway communicates only with motels and cities and Texaco fuel. Because that it the real America (16).

A similar tendency is visible in the construction of the city space. In New York, the built environment begins its duplication into the world of the "old natural:"

I argue that Brooklyn does not end on the shore of Jamaica Bay and at Coney Island, but behind those swings and beaches it continues further under the surface of the sea which is the same grey, endless and submerged into its own thoughts. (...) But above there is not only sky, but a negative print of Brooklyn in mists and smoke. And during a clear night there is no Milky Way above, but Flatbush Avenue and red traffic lights fatefully and irrevocably jumping out there where Sirius and Cassiopeia usually are (24).

What the narrator sees is just a replica of the city, abolishing any reference to the natural environment existing within or around the city.

\section{Conclusion}

In Aškenazy's narrative, a glance at the night sky makes the traveler feel and appreciate the presence of the natural within the urban; in Dubská's travelogue the cities, even though attempting to abolish the natural, are still identities in flux 
subverted by the overwhelming nature beyond their limits; in Holub's travelogues the chances of finding a natural environment radically diminishes as the natural is replaced with its simulacrum: "The endless rumble of automobile herds. Wind and engines. A new nature. I am afraid I like it" (19-20). In any case, the traveler is at ease with the world, which offers a new aesthetic of the natural, whereby the new natural is not as hostile as in Galuška and Hoffmeister's terms, but neutral and authentic: It represents the space as it is. In this way, coming to terms with space in Holub's narrative finalizes the search period for American space in Czech travel writing from the 1950s and 1960s.

Manfred Pfister's argument, cited at the beginning of this article, suggests that space in travel writing is always "at least (...) "half-created" (1996: 3) by the travelers themselves; the transformation of the image of America in Czech travel writing has to be analyzed along the lines of change within the travelers' identities. The process starts with a clear identification of the leading ideology (Galuška and Hoffmeister), shifts to cultural identification with Europe (Aškenazy), is additionally defined by the specific character of the urban space (Dubská), and culminates in a conscious avoidance of references to anything other than the artistic (Holub). The final stage in this development also represents a reconnection with American literature, which, to various extents, constructs the image of America as seen through the eyes of its poets. However, this tendency has been only briefly outlined; due to its complexity it deserves an article of its own and, as such, is part of my ongoing research.

\section{REFERENCES}

Aškenazy, Ludvík. 1956. Indiánské léto [Indian Summer]. Prague: Československý 
Spisovatel.

Aškenazy, Ludvík. 1955. Všude jsem potkal lidi [Everywhere I Met People]. Prague:

Československý spisovatel.

Barthes, Roland. 1986. "Semiology and the Urban." Pp. 87-98 in The City and the Sign. An Introduction to Urban Semiotics, eds. Mark Gottdiener and Alexandros Lagopoulos. New York: Columbia University Press.

Bauer, Michal. 2003. "The Portrayal of the United States in Miroslav Holub's Writing From the 1960s," presented at 2003 SVU North American Conference, Cedar Rapids, Iowa, 26-28 June 2003, http://svu2000.org/conferences/2003_Iowa/38.pdf (accessed 2 December 2014)

Borovička, Michael. 2010. Velké dějiny zemí Koruny české. Cestovatelství. Prague; Lytomyšl: Paseka.

Čapek, Abe. 1956. "Introduction.” Pp. 5-26 in Whitman, Walt. O poesii, národní kulture a jazyku [On Poetry, National Culture and Language]. Trans. Zdeněk Urbánek. Prague: Československý spisovatel.

De Certeau, Michel. 1984. "Walking in the City." Pp. 91-110 in The Practice of Everyday Life, trans. Steven Rendall. Los Angeles, London: California University Press.

Dubská, Irena. 1966. Americký rok [American Year]. Prague: Československý spisovatel.

Hanzelka, Jiří, and Miroslav Zikmund. 1997. Život snů a skutečnosti [Life of Dreams and Reality]. Prague: Primus.

Ferlinghetti, Lawrence. 1958. A Coney Island of the Mind. New York: New Directions Books.

Hájek, Igor. 1959. "Americká bohéma” [American boeme]. Světová literatura 6: 207230.

Hoffmeister, Adolf, and Galuška, Miroslav. 1951. Tři měsíce v New Yorku [Three Months in New York]. Prague: Rudé právo.

Holub, Miroslav. 1963. Anděl na kolečkách [Angel on Wheels]. Prague: Československý spisovatel.

Kahoun, František. 1952. "Gottwaldovy stupně míru” [Gottwald's Steps of Peace]. Lidé a zemé 1, no. 1: 3-6.

Margolin, Uri. 2000. "Telling in the Plural: From Grammar to Ideology." Poetics Today 21, no. 3: 591-618. 
Mocná, Dagmar, and Josef Peterka, eds. Encyklopedie literárních žánrů [Encyclopedia of Literary Genres]. Praha; Litomyšl: Paseka, 2004.

Pfister, Manfred. 1996. "To Go Abroad and See the World." Pp. 3-21. Introduction to The Fatal Gift of Beauty. The Italies of British Travelers. Ed. Manfred Pfister. Amsterdam; Atlanta: Rodopi.

Pírková Jakobson, Svatava. 1957. "Prague and the Purple Sage.” Harvard Slavic Studies 3: 247-87

Richardson, Brian. 2009. "Plural Focalization, Singular Voices: Wandering Perspectives in 'We'- Narration.” Pp. 143-162 in Point of View, Perspective, and Focalization: Modeling Mediation in Narrative, eds. Peter Hühn, Wolf Schmid, Jörg Schönert. Berlin: Walter de Gruyter.

Robbins, Vernon Kay. 1978. "By Land and By Sea: The We-Passages and Ancient Sea Voyages." Pp. 215-242 in Perspectives on Luke-Acts, ed. Charles H. Talbert. Macon: GA.: Mercer UP \& Edinburgh: T. \& T. Clark, 1978.

Skopal, Pavel. 2008. "Na cestu kolem světa, nebo na výlet do Krče? Recepce filmových cestopisů Hanzelky a Zikmunda v 50. letech" [A Journey Around the World or A Trip to Krč? Reception of Hanzelka's and Zikmund's Film Travelogues in the 1950s]. Iluminace 20, no. 1: 85-123.

Quinn, Justin. 2014. "California Dreaming: Miroslav Holub and Seamus Heaney." Pp. 177-199 in Ireland and the Czech Lands, eds. Onřej Pilný and Gerald Power. New York: Peter Lang.

Wirth-Nesher, Hana. 2001. "Impartial Cities: Reading and Writing Cities" Pp. 52-67 in Handbook of Urban Studies, ed. Ronan Paddison. London: Sage Publications Ltd. doi: 10.4135/9781848608375

Zábrana, Jan. 1959. Pátá roční doba. Americká radikální poezie [The Fifth Season of the Year. American Radical Poetry]. Prague: Mladá fronta.

Zábrana, Jan. 1967. Obeznámení s nocí. Noví američtí básníci [Familiar With Night. New American Poets]. Prague: Československý spisovatel.

Zapletal, Ladislav. 1957. "O mrakodrapech a výškových stavbách” [On Skyscrapers and High-Rises]. Lidé a zemé 6, no. 2: 74-77. 


\section{ACKNOWLEDGMENTS}

This article as a whole is a part of the project CZ 1.07/2.3.00/30.0004. Research undertaken for this article at the University of Toronto was generously supported by a research grant awarded by The Carnegie Trust for the Universities of Scotland. I would like to thank Dr David Lightfoot for reading and providing insightful comments on the article.

\section{NOTES}

${ }^{1}$ Collectively known as Zikmund \& Hanzelka, the duo was famous for their statesponsored world tours in Czechoslovak-made Tatra cars, and for the books, radio reports, and films produced during their travels. From 1947 to 1950, they traveled across Africa before moving to South America, and from 1959 to 1964 through Asia, Oceania and the Soviet Union. They had a cult following among the postwar Czech populace, and, as Pavel Skopal writes, their popularity was comparable to the successes of the world-renowned Czechoslovak Olympian Emil Zátopek (2008: 86).

2 The term "travel narratives" refers to the reportage and travel writing genres which in this period were often methodologically conflated. For instance, in the Encyclopedia of Literary Genres (Encyklopedie literárních žánrů, 2004) many postwar narratives are categorized under both headings (and even as "travel reportage"), among them, for instance, Miroslav Holub's Angel on Wheels (Andèl na kolečkách, 1963) (“cestopis,” 2004: 81; “reportáže” 2004: 572).

${ }^{3}$ Because of the shortness of space, some highly informative narratives written by other journalists and writers, such as Karel Kyncl's (1927-1997) reportages or Norbert Frýd's (1913-1976) articles, will not be discussed. 
${ }^{4}$ Miroslav Galuška (1922-2007) was a reporter, diplomat, and politician. Adolf Hoffmeister (1902-1973) was a prominent Czech writer, artist, traveler, and diplomat. The report was first published as a series of articles in the daily Red Justice (Rudé právo) on the occasion of the UN General Assembly in New York in 1951.

${ }^{5}$ Ludvik Aškenazy (1921-1986) was a journalist and a writer known for his travel reportage and literature for children.

${ }^{6}$ Irena Dubská (1924-2010) was a Czech sociologist and philosopher. American Year, as well as the study Discovering America (Objevováni Ameriky, 1964), were inspired by her study leave at MIT in the period between 1963 and 1964 .

7 Miroslav Holub (1923-1998) was an immunologist and writer, internationally known for his poetry collections. On the reception of Holub in the Anglophone world, see Quinn: 2014.

${ }^{8}$ Holub's other American travelogue, To Live in New York (Žit v New Yorku, 1969), will not be discussed because it shares many narrative strategies analyzed in this article (even though it represents America more pessimistically). Although Holub's Angel on Wheels emerged three years before Dubská's American Year, I decided to go against the chronological approach: while in both travelogues America is represented similarly, Holub's work is a kind of a climax, in which references to contemporary American poets of Beat generation, are, in contrast to Dubská's, explicit.

9 The idea of the "bright Socialist world" was not entirely new: it represents a continuation of a similar notion as expressed in the interwar reportage.

10 The term "collective narrative agent" is borrowed from Uri Margolin's article "Telling in the Plural: From Grammar to Ideology" (2000), and will be discussed later in the article. 
11 The reportage functions as a collective "we" narrative, even though in the introduction the authorship of individual contributions is clearly divided.

${ }^{12}$ Uri Margolin emphasizes the importance of historical memory and the "obligation [of members] to preserve and continue the heritage of previous generations, since they regard the past as a significant or even decisive part of what constitutes their own shared social identity" (2002: 607). In postwar reportage (e.g. Aškenazy 1955), historical memory relates to the traumatic experience of WWII. The representation of America was ambivalent, as America's crucial role as the liberator of Czechoslovakia was marginalized in the postwar years due to America's subsequent involvement in wars elsewhere that were negatively perceived. Galuška/Hoffmeister's reportage represents Czechoslovak citizens as educated in comparison with their American counterparts and constructs the opposition between them as a civilizational one: "Residents of Western Bohemia, where American troops arrived in May of 1945, until today have told stories about the illiteracy and naivety of Americans. It happened that our people began discussions about American literature with American soldiers; they inquired about Upton Sinclair, Sinclair Lewis, Theodor Dreiser (...) They [American soldiers] did not know those names" (1951: 76).

13 Similar comparisons continue to appear throughout the period. For example, Ladislav Zapletal considered sky-scrapers signs of an emerging epoch and considered American ones to be comparatively "dirty, unhygienic" and aesthetically damaging, while the Soviet ones were in harmony with the cultural heritage (1957: 77).

14 The word "drugstore" is italicized and used in its English form in the text.

${ }^{15}$ German journalist and author of a study of contemporary America titled The Unfinished Society (Die unfertige Gesellschaft 1961).

${ }^{16}$ Italics are used in the original text. 
${ }^{17}$ Justin Quinn's argument is based on the balancing act to which writers of that time had to abide: Holub had to criticize America in order to satisfy the ideologically controlled discourse of Communist Czechoslovakia in order to be able to show "his intensive involvement with American culture and life" (2014: 188).

${ }^{18}$ Jan Zábrana (1931-1984) was a Czech writer and translator.

${ }^{19}$ For a discussion of the American influence on Czech interwar literature and culture, see Pírková-Jakobson: 1957.

20 "The land without wrinkles" is the metaphor Irena Dubská refers to in her travelogue in the context of admiration of American culture, especially of the phenomenon of history in the making (1966: 326). 